\title{
Copper gettering by aluminum precipitates in aluminum-implanted silicon
}

\section{G. A. Petersen and S. M. Myers}

Sandia National Laboratories, Dept. 1112, Mail Stop 1056, P.O. Box 5800, Albuquerque, NM 87185-1056, USA

Copper in $\mathrm{Si}$ is shown to be strongly gettered by Al-rich precipitates formed by implanting $\mathrm{Al}$ to supersturation and followed by annealing. At temperatures ranging from 600 to $800^{\circ} \mathrm{C}$ a layer containing $\mathrm{Al}$ precipitates is found to getter $\mathrm{Cu}$ from $\mathrm{Cu}$ silicide located on the opposite side of a $0.25-\mathrm{mm}$ Si wafer, indicating a substantially lower chemical potential for the $\mathrm{Cu}$ in the molten$\mathrm{Al}$ phase. $\mathrm{Cu}$ gettering proceeds rapidly until an atomic ratio of approximately $2 \mathrm{Cu}$ atoms to 1 $\mathrm{Al}$ atom is reached in the precipitated $\mathrm{Al}$ region, after which the gettering process slows. Redistribution of $\mathrm{Cu}$ from one $\mathrm{Al}$-rich layer to another at low $\mathrm{Cu}$ concentrations demonstrates that a segregation-type gettering mechanism is operating. $\mathrm{Cu}$ gettering occurs primarily in the region containing the precipitated $\mathrm{Al}$ rather than the region where the $\mathrm{Al}$ is entirely substitutional. 


\section{DISCLAIMER}

This report was prepared as an account of work sponsored by an agency of the United States Government. Neither the United States Government nor any agency thereof, nor any of their employees, make any warranty, express or implied, or assumes any legal liability or responsibility for the accuracy, completeness, or usefulness of any information, apparatus, product, or process disclosed, or represents that its use would not infringe privately owned rights. Reference herein to any specific commercial product, process, or service by trade name, trademark, manufacturer, or otherwise does not necessarily constitute or imply its endorsement, recommendation, or favoring by the United States Government or any agency thereof. The views and opinions of authors expressed herein do not necessarily state or reflect those of the United States Government or any agency thereof. 


\section{DISCLAIMER}

Portions of this document may be illegible in electronic image products. Images are produced from the best available original document. 


\section{Introduction}

Transition-metal impurities can degrade Si-based devices by introducing deep electronic levels into the $\mathrm{Si}$ band gap, and by precipitating at critical $\mathrm{Si} / \mathrm{SiO}_{2}$ interfaces, causing electrical breakdown. ${ }^{1}$ These effects are enhanced by the rapid diffusion of transition-metal impurities in $\mathrm{Si}$, which allows metal-silicide precipitates to grow by drawing metal atoms from the macroscopic wafer volume during processing. ${ }^{2,3}$ In order to control this degradation, Si device manufacturers generally supplement stringent clean-room procedures with gettering, whereby transition-metal impurities are removed from the device region of the wafer by transport to remotely located sinks. Gettering is usually implemented using one or more of three approaches $^{3}$ : 1) formation of a region with preferred nucleation sites for metal silicide precipitation, such as point defects or $\mathrm{SiO}_{2}$ precipitates (relaxation-induced gettering), ${ }^{1,3}$ 2) creation of a zone with increased impurity solubility (segregation-induced gettering), such as Albackside gettering ${ }^{4}$, or 3 ) P-diffusion gettering, which involves dynamic processes arising from interstitial-defect gradients (injection-induced gettering). ${ }^{1,5}$

While relaxation-induced gettering is effective, it is limited by the fact that the solution concentration of a metal impurity can be reduced to the thermodynamic solid solubility and no further. This solubility exceeds acceptable impurity levels at the elevated temperatures of device processing, requiring subsequent gettering at lower temperatures. Also, if a metal silicide particle precipitates at a critical device location, such as the base of a gate oxide, no driving force exists to dissolve the particle, since the metal chemical potentials at the particle and the silicide sink are the same. In contrast, segregation-induced gettering and injection-induced gettering remain active at all metal impurity concentrations. ${ }^{6}$

Gettering of several transition metals by $\mathrm{Al}$ in $\mathrm{Si}$ has been investigated previously., ${ }^{4,9}$ Evaporated $\mathrm{Al}$ films were found to getter $\mathrm{Fe}^{4}$ and $\mathrm{Co}^{7}$ as well as $\mathrm{Cu}$ and $\mathrm{Ni}$ below the Al-Si eutectic temperature, $577^{\circ} \mathrm{C}{ }^{8}$ Also, an $\mathrm{Al}$ doped Si layer with dopant concentrations below the solid solubility was found to getter $\mathrm{Cu}, \mathrm{Ni}$, and $\mathrm{Au}^{9}{ }^{9}$ 
In the present paper, we describe the gettering of $\mathrm{Cu}$ by $\mathrm{Al}$ precipitates within the $\mathrm{Si}$ matrix at temperatures from 600 to $800^{\circ} \mathrm{C}$, above the eutectic where the Al-Si phase is molten. The precipitates were formed by implanting $\mathrm{Al}$ to levels above the solid solubility and then annealing. Aspects investigated include the stability of the gettered state relative to that of the $\mathrm{Cu}_{3} \mathrm{Si}$ phase, the maximum concentration of strongly gettered $\mathrm{Cu}$ in the precipitated $\mathrm{Al}$ phase, the segregation character of the gettering mechanism, and the dominance of the Al-precipitation gettering over gettering by substitutional $\mathrm{Al}$.

\section{Materials and Experimental Techniques}

Two types of experiment were carried out in order to characterize $\mathrm{Cu}$ gettering by $\mathrm{Al}$ precipitates. In the first, $0.25 \mathrm{~mm}$-thick, double-side polished float-zone (111) Si samples were implanted on one side with $1 \times 10^{16} \mathrm{Al} / \mathrm{cm}^{2}$ at an energy of $180 \mathrm{keV}$, with an average projected range of $300 \mathrm{~nm}$. The specimen was then annealed at $800^{\circ} \mathrm{C}$ for 1 hour to induce $\mathrm{Al}$ precipitation and activation of substitutional Al. All anneals were done in a continuously ion pumped quartz furnace tube. The pressure during the anneals was $\sim 10^{-7} \mathrm{Torr}$ and the anneal was concluded by removing the tube from the furnace and allowing the samples to cool to room temperature under vacuum. It has previously been found that when $\mathrm{Al}$ is ion-implanted into $\mathrm{Si}$ at levels above the solubility and then annealed, the $\mathrm{Al}$ precipitates into a double-peak structure in the region where the $\mathrm{Al}$ concentration exceeds its solid solubility, $\left(\sim 10^{19} \mathrm{~cm}^{-3} \text { at } 700^{\circ} \mathrm{C}\right)^{10}$ with a diffusion tail of substitutional Al extending to greater depths. ${ }^{11-14}$ Similar behavior was observed in our experiments. The $800^{\circ} \mathrm{C}$ anneal was followed by an implant of $1 \times 10^{17} \mathrm{Cu} / \mathrm{cm}^{2}$ on the opposite side of the wafer at an energy of $150 \mathrm{keV}$, giving an average projected range of $125 \mathrm{~nm}$. As shown previously, this treatment leads to the formation of $\mathrm{Cu}_{3} \mathrm{Si}$ during subsequent annealing at temperatures of $600^{\circ} \mathrm{C}$ or greater. ${ }^{15}$ As a result, the silicide acted as a continuous source of metal atoms to solution, thereby stabilizing the adjacent solution concentration of $\mathrm{Cu}$ at the solid solubility during the vacuum gettering anneals at 600,700 , and $800^{\circ} \mathrm{C}$. During the 
anneals, the redistribution of the $\mathrm{Cu}$ from the $\mathrm{Cu}_{3} \mathrm{Si}$ to the $\mathrm{Al}$ precipitated region was measured as a function of anneal time.

The second type of experiment also used $0.25 \mathrm{~mm}$ double-side polished float-zone (111) Si samples. These samples were implanted with $1 \times 10^{16} \mathrm{Al} / \mathrm{cm}^{2}$ at an energy of $180 \mathrm{keV}$ on both sides and annealed at $800^{\circ} \mathrm{C}$ for 1 hour to form the $\mathrm{Al}$ precipitates at a range of $300 \mathrm{~nm}$. Copper was then implanted on one side to a dose of $3.4 \times 10^{15} \mathrm{Cu} / \mathrm{cm}^{2}$ at an energy of $150 \mathrm{keV}$, locating the $\mathrm{Cu}$ in a range between the surface and the precipitated $\mathrm{Al}$ layer and centered at depth of 125 nm. Subsequent vacuum annealing at $700^{\circ} \mathrm{C}$ caused the $\mathrm{Cu}$ to diffuse to the $\mathrm{Al}$ regions, first to the closest Al layer and then across the wafer to the second layer.

Rutherford backscatterring spectrometry (RBS) and secondary-ion mass spectrometry (SIMS) were used to measure the diffusive redistribution of metal atoms in both the Cu silicideto-Al layer experiment and the Al layer-to-Al layer experiment. The SIMS concentration measurements were calibrated using low-dose ion-implanted Si standards; the sensitivity was $\sim 10^{15} \mathrm{~cm}^{-3}$ for both $\mathrm{Cu}$ and $\mathrm{Al}$. An inherent limitation of SIMS is the difficulty of measuring high ( $\geq 1.0$ at. $\%$ ) concentrations of the metal impurity atoms in a Si matrix due to non-linearities in sputtering. This is illustrated in Figure 1a, where a comparison of the depth profiles from both SIMS and RBS of $\mathrm{Cu}$ gettered to an $\mathrm{Al}$ layer in $\mathrm{Si}$ is shown. The two profiles have similar shape, however, when calculating the areal density, the SIMS result gave a $20 \%$ higher value than the RBS result. Thus, RBS is better suited to the task of measuring the $\mathrm{Cu}$ in these samples containing higher $\mathrm{Cu}$ concentrations. Figure $\mathrm{lb}$ shows the RBS versus SIMS concentration profiles for $\mathrm{Cu}$ in an $\mathrm{Al}$ layer where the concentration of $\mathrm{Cu}$ in $\mathrm{Si}$ is less than $0.5 \%$. Here, the resulting RBS and SIMS data are much more comparable. Because of the limited sensitivity of RBS, SIMS data was better suited for measurements of the $\mathrm{Cu}$ impurity concentrations in the concentration regime below 0.5 at.\%. In all cases the peak $\mathrm{Al}$ concentrations were on the order of 1.0 at.\% in $\mathrm{Si}$, and since $\mathrm{RBS}$ is not well suited to measure $\mathrm{Al}$ in $\mathrm{Si}$, the $\mathrm{Al}$ concentrations were taken from SIMS. 


\section{Results}

The first type of experiment involved the redistribution of metal atoms from a $\mathrm{Cu}$ silicide layer to a layer containing molten Al-Si precipitates. Figure 2 shows the areal density of the gettered $\mathrm{Cu}$ in the $\mathrm{Al}$ region for 600,700 , and $800^{\circ} \mathrm{C}$ versus anneal time as measured by RBS. Also shown is the calculated accumulation rate for steady-state diffusion of $\mathrm{Cu}$ from $\mathrm{Cu}_{3} \mathrm{Si}$ to a strong sink. This flux is given by:

$$
\Phi \cong \mathrm{C}_{\mathrm{sol}} \mathrm{D} / \Delta \mathrm{x}
$$

where $\mathrm{C}_{\text {sol }}$ is the metal solid solubility, $\mathrm{D}$ is the metal diffusion coefficient, and $\Delta \mathrm{x}$ is the average interlayer diffusion distance. At each temperature, the values of $\mathrm{C}_{\text {sol }}{ }^{16}$ and $\mathrm{D}^{17}$ were obtained from the literature. For the three temperatures studied, the amount of gettered $\mathrm{Cu}$ accumulated rapidly to an areal density of approximately $2 \times 10^{16} \mathrm{~cm}^{-2}$, or about twice the implanted dose of Al. This was followed by continued gettering, but at a slower rate. Note that the observed rate of redistribution agrees quite well with the rate calculated for diffusion-limited flow, until the point where the gettering slowed. Rutherford backscattering spectrometry after the final anneal showed that $\mathrm{Cu}_{3} \mathrm{Si}$ still remained on the source side of the samples, so that the solution concentration of $\mathrm{Cu}$ in this region remained close to the solid solubility.

Figures $3 \mathrm{a}$ and $3 \mathrm{~b}$ show the concentration profiles of the $\mathrm{Al}$ and $\mathrm{Cu}$ in the gettering layer at $600^{\circ} \mathrm{C}$ and $800^{\circ} \mathrm{C}$, respectively, as measured by SIMS after the final anneals. The precipitated Al double-peak structure described by others in previous works is seen. ${ }^{11-14}$ The SIMS data show a proportionality between the concentrations of precipitated $\mathrm{Al}$ and the gettered $\mathrm{Cu}$ at depths where the $\mathrm{Al}$ is precipitated. At greater depths where the $\mathrm{Al}$ concentration is below the solubility, and therefore not precipitated, the gettering of $\mathrm{Cu}$ is much less pronounced. This indicates that the precipitated $\mathrm{Al}$ gettered $\mathrm{Cu}$ much more strongly than substitutional $\mathrm{Al}$. In a separate experiment, increasing the implanted dose of $\mathrm{Al}$ by a factor of three resulted in a 
proportional increase in the amount of gettered $\mathrm{Cu}$. At the highest temperatures, $800^{\circ} \mathrm{C}$, there was about a $30 \%$ loss of $\mathrm{Al}$ from the $\mathrm{Al}$ precipitated region. This was probably due to surface segregation of the $\mathrm{Al}$ to form $\mathrm{Al}_{2} \mathrm{O}_{3}$ in the near surface region. An examination of the SIMS data in Figure $3 \mathrm{~b}$ shows a large near-surface $\mathrm{Al}$ peak, presumably arising due to this effect.

The second type of experiment examined the redistribution of metal atoms from one precipitated $\mathrm{Al}$ layer to another. Figure 4 shows the measured areal density of $\mathrm{Cu}$ in the second Al layer after annealing at $700^{\circ} \mathrm{C}$. The dashed line is experimental data from Figure 2 showing the $\mathrm{Cu}$ redistribution from a $\mathrm{Cu}$ silicide to an $\mathrm{Al}-\mathrm{Si}$ layer at $700^{\circ} \mathrm{C}$ and is plotted for comparison. During the first 0.5 hour anneal, the initially implanted $\mathrm{Cu}$ moved quickly into the nearest $\mathrm{Al}$ layer and then diffused to the second layer on the backside of the sample. Approximately $2 \times 10^{15}$ $\mathrm{Cu} / \mathrm{cm}^{2}$ remained in the near-side precipitated $\mathrm{Al}$ layer, while the remainder, $1.4 \times 10^{15} \mathrm{Cu} / \mathrm{cm}^{2}$ went to the second layer. After annealing for one hour, two-thirds of the initially implanted $\mathrm{Cu}$ had diffused across the wafer to the second Al layer. Subsequent annealing showed a reduced, yet still non-zero, gettering rate to the second layer.

Following the final $700^{\circ} \mathrm{C}$ anneal, SIMS analysis was performed to examine the $\mathrm{Al}$ and $\mathrm{Cu}$ concentration profiles on both the front and the backside of the sample. Again there was a direct proportionality between the precipitated $\mathrm{Al}$ and the gettered $\mathrm{Cu}$, with very little $\mathrm{Cu}$ being gettered to the substitutional $\mathrm{Al}$ region. A large variation between the initially implanted amount of $\mathrm{Al}$ in the first layer $\left(1 \times 10^{16} \mathrm{Al} / \mathrm{cm}^{2}\right)$ and the amount remaining after the final anneal $\left(4 \times 10^{15}\right.$ $\mathrm{Al} / \mathrm{cm}^{2}$ ) was seen. This apparent loss of $\mathrm{Al}$ from the sample will be discussed in the following section. Very little Al was lost from the second precipitated Al layer, with $9.4 \times 10^{15} \mathrm{Al} / \mathrm{cm}^{2}$ remaining. The amounts of $\mathrm{Cu}$ gettered to the front and back layers after 2 hours at $700^{\circ} \mathrm{C}$ were $1.3 \times 10^{15} \mathrm{Cu} / \mathrm{cm}^{2}$ and $2.0 \times 10^{15} \mathrm{Cu} / \mathrm{cm}^{2}$, respectively. 


\section{Discussion}

Precipitated $\mathrm{Al}$ strongly gettered $\mathrm{Cu}$ from $\mathrm{Cu}_{3} \mathrm{Si}$ at all of the investigated temperatures. In the initial stage of gettering, the $\mathrm{Cu}$ went into solution from the bound state of the silicide and diffused to the precipitated Al layer on the opposite side of the wafer. The dashed lines in Figure 2 show the predicted rate of redistribution for an infinitely strong sink. The correspondence between these lines and the experimental data suggests that the chemical potential of the gettering sink formed by the $\mathrm{Al}$ precipitates is initially much lower than that of the silicide. When the amount of the $\mathrm{Cu}$ in the sinks rose above a certain level, the process slowed, indicating a weaker driving force or similar chemical potential between the $\mathrm{Cu}$ in the silicide and the $\mathrm{Cu}$ in the precipitated $\mathrm{Al}$ phase. Since the final areal density of $\mathrm{Cu}$ gettered to the $\mathrm{Al}$ precipitated region was more than a factor of two greater than the implanted $\mathrm{Al}$ dose, a strong possibility exists that in addition to the liquid $\mathrm{Al}-\mathrm{Cu}-\mathrm{Si}$ phase, other $\mathrm{Al}-\mathrm{Cu}$ phases precipitated. This would cause a reduction in the gettering rate if the $\mathrm{Cu}$ in the new phase or phases has a chemical potential only slightly lower than that of the $\mathrm{Cu}$ in the $\mathrm{Cu}_{3} \mathrm{Si}$. By studying the phase diagrams of both the binary $\mathrm{Al}-\mathrm{Cu}^{18}$ system and the ternary $\mathrm{Al}-\mathrm{Cu}-\mathrm{Si}^{19,20}$ system, a detailed explanation of the reduction of the gettering rate can be proposed.

Initially, at the elevated temperatures investigated, there exists $\mathrm{Cu}_{3} \mathrm{Si}$ on the source side of the sample, as shown by previous investigations of implanted $\mathrm{Cu}$ in $\mathrm{Si}^{15}$ On the gettering side of the sample, the implanted $\mathrm{Al}$ exists as a molten $\mathrm{Al}-\mathrm{Si}$ phase as observed in previous studies $^{11}$ and as expected at temperatures above the binary Al-Si eutectic. ${ }^{21}$ As $\mathrm{Cu}$ is gettered to the $\mathrm{Al}$ region, a molten $\mathrm{Al}-\mathrm{Cu}-\mathrm{Si}$ mixture develops. As still more $\mathrm{Cu}$ is gettered to the $\mathrm{Al}$ precipitated region, solid phases will precipitate out of the molten liquid. Examination of the ternary phase diagram shows that these phases will essentially consist of binary $\mathrm{Al}-\mathrm{Cu}$ phases with a small amount of $\mathrm{Si}$ included. Based on the Al-Cu binary phase diagram, the initial solid $\mathrm{Al}-\mathrm{Cu}$ phases will precipitate at $\mathrm{Cu}: \mathrm{Al}$ ratios of approximately 0.5 at $600^{\circ} \mathrm{C}$ and 1.0 at $800^{\circ} \mathrm{C}$. As the $\mathrm{Cu}$ concentration increases still further, a succession of single-phase and multi-phase conditions can occur. In this investigation, at all investigated temperatures, the gettering 
proceeds rapidly to a $\mathrm{Cu}: \mathrm{Al}$ ratio of about $2.0-2.5$, at which point the gettering process slows dramatically. The $600^{\circ} \mathrm{C}$ case, shown in Figure 2, allows the most accurate determination of the $\mathrm{Cu}: \mathrm{Al}$ ratio because there is little continued gettering after the gettering rate slows, and there is no significant loss of $\mathrm{Al}$ from the gettering layer. A Cu:Al ratio of 2.3 is measured by SIMS after a total anneal time of 50 hours. The determinations at the higher temperatures are less accurate due to the evolution of the system after the slowdown of the gettering process, and the loss of some $\mathrm{Al}$ from the precipitated $\mathrm{Al}$ layer. However, by examining Figure 2 at the point where the initial gettering slows, and assuming a nominal $\mathrm{Al}$ areal density of $10^{16} \mathrm{Al} / \mathrm{cm}^{2}$ (no $\mathrm{Al}$ loss), a $\mathrm{Cu}: \mathrm{Al}$ ratio of approximately 2.3 for both the 700 and $800^{\circ} \mathrm{C}$ cases can be extracted. According to the binary phase diagram, this concentration corresponds closely to the $\gamma_{1}$-phase of the $\mathrm{Al}-\mathrm{Cu}$ binary, which has a nominal composition of $\mathrm{Al}_{4} \mathrm{Cu}_{9}$, or a $\mathrm{Cu}: \mathrm{Al}$ ratio of 2.25 . The reduction in the gettering rate is then believed to occur when the $\mathrm{Cu}: \mathrm{Al}$ ratio rises above that of the $\gamma_{1}$-phase of the Al-Cu alloy, where still more $\mathrm{Cu}$-rich phases are expected to form. In this region, the difference in the $\mathrm{Cu}$ chemical potential between the $\mathrm{Al}-\mathrm{Cu}$ alloy and the $\mathrm{Cu}_{3} \mathrm{Si}$ source phase has become small.

Figures $3 \mathrm{a}$ and $3 \mathrm{~b}$ display the near proportionality between the concentrations of the precipitated $\mathrm{Al}$ and the gettered $\mathrm{Cu}$. The $\mathrm{Cu}$ was gettered much more strongly to the precipitated $\mathrm{Al}$ phase than to the substitutional $\mathrm{Al}$, as evidenced by the $\mathrm{Cu}: \mathrm{Al}$ ratio being much greater in the region containing the precipitated $\mathrm{Al}$ than in the region containing substitutional $\mathrm{Al}$ alone. Moreover, as was mentioned earlier, when the implanted $\mathrm{Al}$ dose was increased by a factor of three, a proportional increase in the amount of gettered $\mathrm{Cu}$ resulted. While gettering by substitutional Al has been reported elsewhere, ${ }^{9}$ substitutional gettering was not seen in the present experiments where a precipitated $\mathrm{Al}$ phase was present, suggesting that gettering by substitutional $\mathrm{Al}$ is less energetically preferred.

In the second type of experiment performed in this study, the redistribution of $\mathrm{Cu}$ from one precipitated $\mathrm{Al}$ layer to another was examined. The total amount of $\mathrm{Cu}$ implanted into the system was sufficiently small to prevent precipitation of $\mathrm{Al}-\mathrm{Cu}$ solid phases in addition to the 
molten $\mathrm{Al}-\mathrm{Cu}-\mathrm{Si}$ phase. When annealed, the initially implanted $\mathrm{Cu}$, located near the first precipitated $\mathrm{Al}$ layer, moves quickly into that layer. Within the precipitated $\mathrm{Al}$ layers, as the $\mathrm{Cu}$ concentration increases, the chemical potential of the $\mathrm{Cu}$ also increases. The chemical potential difference between the two layers results in a driving force to redistribute the $\mathrm{Cu}$ from the first layer containing a higher $\mathrm{Cu}$ concentration to the second layer containing a lower $\mathrm{Cu}$ concentration. So, as the anneal continues, $\mathrm{Cu}$ is gettered to the second precipitated $\mathrm{Al}$ layer from the first until the redistributive flow stops and the chemical potential between the two gettering layers becomes equal. Upon completion of the redistribution, the $\mathrm{Cu}: \mathrm{Al}$ ratio in the two precipitated layers should be equal.

After annealing the sample at $700^{\circ} \mathrm{C}$ for two hours, SIMS analysis of both sides of the sample showed a $60 \%$ loss of $\mathrm{Al}$ from the first layer and little to no loss from the second layer, resulting in sink layers that were no longer identical. The second layer, with more precipitated $\mathrm{Al}$, gettered more $\mathrm{Cu}$ than the first layer. Measuring the gettered amount of $\mathrm{Cu}$ in the first and second precipitated $\mathrm{Al}$ layers yielded $\mathrm{Cu}: \mathrm{Al}$ ratios of 0.32 and 0.22 , respectively. Examination of the $\mathrm{Al}-\mathrm{Cu}$ binary phase diagram at $700^{\circ} \mathrm{C}$ showed that for the above $\mathrm{Cu}: \mathrm{Al}$ ratios, the gettering phase is still entirely liquid, suggesting that the redistribution was occurring as described above. However with the simultaneous loss of $\mathrm{Al}$ from the first precipitated layer, full equilibration between the two layers may not have been achieved, thereby accounting for the greater $\mathrm{Cu}: \mathrm{Al}$ ratio in first layer.

In principle, the redistribution of $\mathrm{Cu}$ between the two molten Al-Si sinks can be used to determine a value for the activation energy associated with the transfer of one $\mathrm{Cu}$ metal atom from its bound state in the precipitated Al into interstitial solution. However, due to complications arising from the loss of $\mathrm{Al}$ from the first $\mathrm{Al}-\mathrm{Si}$ layer during the gettering anneal, quantification of the activation energy was not performed. The Al loss occurred only on the side of the wafer which contained the initially implanted $\mathrm{Cu}$ and not from the second $\mathrm{Al}$ layer. Possibly, the loss of $\mathrm{Al}$ from the first layer is due to an enhanced surface-segregation of the $\mathrm{Al}$ due to near-surface implant damage caused by the $\mathrm{Cu}$ implantation that followed the formation 
of the $\mathrm{Al}$ precipitates. Further annealing at the gettering temperatures might allow for enhanceddiffusion of the $\mathrm{Al}$ to the surface.

A more qualitative conclusion was obtained by comparing the $700^{\circ} \mathrm{C}$ experimental data in Figure 2, showing the $\mathrm{Cu}$ redistribution from $\mathrm{Cu}_{3} \mathrm{Si}$ to a molten $\mathrm{Al}-\mathrm{Cu}-\mathrm{Si}$ layer, to the data in Figure 4, showing the $\mathrm{Cu}$ redistribution at $700^{\circ} \mathrm{C}$ between molten $\mathrm{Al}-\mathrm{Cu}-\mathrm{Si}$ layers. For a more direct comparison, the dashed line of Figure 4 is the $700^{\circ} \mathrm{C}$ data of Figure 2 re-plotted. In both cases, the gettering layer consisted of Al-Si precipitates on the opposite side of the sample. A key point is that the $\mathrm{Cu}$ redistribution from one $\mathrm{Al}-\mathrm{Si}$ layer to another is more than a factor of 3 times slower than the $\mathrm{Cu}$ redistribution from $\mathrm{Cu}_{3} \mathrm{Si}$ to an $\mathrm{Al}-\mathrm{Si}$ layer. Assuming that the diffusion coefficient for $\mathrm{Cu}$ in $\mathrm{Si}$ at $700^{\circ} \mathrm{C}$ for both experiments is equal, then the statement can be made that the solution concentration of $\mathrm{Cu}$ in the vicinity of the $\mathrm{Al}-\mathrm{Si}$ precipitates is lower than the solution concentration of $\mathrm{Cu}$ near the $\mathrm{Cu}_{3} \mathrm{Si}$, implying the corresponding $\mathrm{Cu}$ chemical potential difference. This is as expected given that the first set of experiments displayed the ability of the $\mathrm{Al}-\mathrm{Si}$ precipitates to getter substantial amounts of $\mathrm{Cu}$ from $\mathrm{Cu}_{3} \mathrm{Si}$.

As mentioned earlier, at impurity concentrations $<1.0$ at. $\%$ in $\mathrm{Si}$, SIMS is more quantitative than at higher concentrations and provides higher sensitivity than RBS. Figure 5 shows the concentration profiles of the $\mathrm{Cu}$ and the $\mathrm{Al}$ in the second layer after annealing at $700^{\circ} \mathrm{C}$ for 2 hours as measured by SIMS. Examination of the $\mathrm{Cu}: \mathrm{Al}$ ratios in the precipitated and the substitutional regions reveals that the ratio in the precipitated phase is more than 10 to 100 times greater than the ratio in the substitutional $\mathrm{Al}$ region. This again shows that the $\mathrm{Cu}$ is gettered much more strongly to the precipitated liquid Al-Si phase.

\section{Conclusions}

Implanted and annealed $\mathrm{Al}$ in $\mathrm{Si}$ formed precipitates when the $\mathrm{Al}$ concentration exceeded the solid solubility. These precipitates strongly gettered $\mathrm{Cu}$ at elevated temperatures ranging from $600^{\circ} \mathrm{C}$ to $800^{\circ} \mathrm{C}$, dissolving $\mathrm{Cu}_{3} \mathrm{Si}$ located on the opposite side of a $0.25-\mathrm{mm} \mathrm{Si}$ wafer, and 
gettering more than $2 \mathrm{Cu}$ atoms per atom of implanted $\mathrm{Al}$. At all investigated temperatures, the gettering proceeded relatively rapidly to a $\mathrm{Cu}: \mathrm{Al}$ ratio of about 2.3 , at which point the gettering process slowed. This transitional atomic ratio corresponds to the $\gamma_{1}$-phase of the Al-Cu binary system. When precipitated $\mathrm{Al}$ was present, gettering of $\mathrm{Cu}$ to substitutional $\mathrm{Al}$ sites was negligible compared to the gettering of $\mathrm{Cu}$ to the molten Al-Si phase. It was determined that the $\mathrm{Cu}$ chemical potential in the precipitated $\mathrm{Al}$ region increases with increasing $\mathrm{Cu}$ concentration, and that the binding free energy of $\mathrm{Cu}$ in the liquid $\mathrm{Al}-\mathrm{Si}$ precipitates relative to solution was much larger than that of $\mathrm{Cu}$ in $\mathrm{Cu}_{3} \mathrm{Si}$. These results suggest that the use of $\mathrm{Al}$ precipitates is technologically attractive for applications requiring the removal of $\mathrm{Cu}$ impurities from $\mathrm{Si}$ over extended diffusion distances in order to improve the material's electronic properties. Examples of such applications would include improved efficiencies and minority carrier diffusion lengths in silicon solar cells, and reduced impurity levels in $\mathrm{Si}$ used for microelectronic device processing, resulting in higher device yields.

\section{Acknowledgements}

This work was supported by the United States Department of Energy, Office of Basic Energy Sciences, under Contract No. DE-AC04-94AL85000. Sandia is a multiprogram laboratory operated by the Sandia Corporation, a Lockheed Martin Company, for the U.S. Department of Energy. 


\section{References}

1. K. Graff, Metal Impurities in Silicon-Device Fabrication (Springer, Berlin, 1995).

2. E. R. Weber, in Properties of Silicon (INSPEC, New York, 1988) pp. 409-451.

3. W. Schröter, M. Seibt, D. Gilles, in Materials Science and Technology, Vol. 4; Electronic Structure and Properties of Semiconductors, ed. W. Schröter (VCH, New York, 1991) pp. 539-589.

4. H. Hieslmair, S. McHugo, E. R. Weber, "Aluminum Backside Segregation Gettering," Proceedings of the $25^{\text {th }}$ IEEE Photovoltaic Specialists Conference, IEEE, Washington, D.C., May 13-17, 1996, pp. 441-444.

5. D. Gilles, W. Schröter, and W. Bergholz, Phys. Rev. B 41, 5770 (1990).

6. S. M. Myers, G. A. Petersen, T. J. Headley, J. R. Michael, T. L. Aselage, and C. H. Seager, Nucl. Instr. And Meth. B 127/128 291 (1997).

7. M. Apel, I. Hanke, R. Schindler, and W. Schröter, J. Appl. Phys. 76, 4432 (1994).

8. R. D. Thompson and K. N. Tu, Appl. Phys. Lett. 41, 440 (1982).

9. L. A. Verhoef, P.-P. Michiels, S. Roorda, and W. Sinke, Mater. Sci. Eng. B 7, 49 (1990).

10. D. de Cogan, in: Properties of Silicon (INSPEC, New York, 1988) pp. 386-387.

11. D. K. Sadana, M. H. Norcott, R. G. Wilson, and U. Dahmen, Appl. Phys. Lett. 49, 1169 (1986).

12. G. Galvagno, A. Scandurra, V. Raineri, C. Spinella, A. Torrisi, A. La Ferla, V. Sciascia, and E. Rimini, J. Electrochem. Soc. 140, 2313 (1993).

13. G. Galvagno, A. Scandurra, V. Raineri, E. Rimini, A. La Ferla, V. Sciascia, F. Frisina, M. Raspagliesi, and G. Ferla, Nucl. Instr. And Meth. B 74105 (1993).

14. G. Galvagno, A. La Ferla, C. Spinella, F. Priolo, V. Raineri, L. Torisi, E. Rimini, A. Carnera, and A Gasparotto, J. Appl. Phys. 76, 2070 (1994).

15. S. M. Myers and D. M. Follstaedt, J. Appl. Phys. 79, 1337 (1996).

16. E. R. Weber, Appl. Phys A 30, 1 (1983).

17. A. A. Istratov, C. Flink, H. Hieslmair, and E. R. Weber, Phys. Rev. Lett. 81, 1243 (1998). 
18. J. L. Murray, Int. Met. Rev. 30, 211 (1985).

19. H. L. Lukas, in Ternary Alloys: Vol. 5, $\mathrm{Al}-\mathrm{Cu}-\mathrm{S}$ to $\mathrm{Al}-\mathrm{Gd}-\mathrm{Sn}$, eds. G. Petzow and G. Effenberg (VCH, Weinheim, Germany and New York, NY, 1992) pp. 11-21.

20. P. Villars, A. Prince, and H. Okamoto, in Handbook of Ternary Alloy Phase Diagrams: Volume 3, (ASM International, Materials Park, OH, 1995) pp. 3330-3350.

21. J. L. Murray and A. J. McAlister, Bull. Alloy Phase Diagrams 5, 74 (1984). 


\section{Figure Captions}

FIG. 1. Comparison of the RBS and SIMS profiles of $\mathrm{Cu}$ in a precipitated $\mathrm{Al}$ layer: (a) after annealing at $600^{\circ} \mathrm{C}$ for 50 hours resulting in a $\mathrm{Cu}$ concentration $>1.0$ at.\%; (b) after annealing at $700^{\circ} \mathrm{C}$ for 2 hours resulting in a $\mathrm{Cu}$ concentration $<1.0$ at. $\%$.

FIG.2. Diffusive redistribution of $\mathrm{Cu}$ from $\mathrm{Cu}_{3} \mathrm{Si}$ layer to a precipitated $\mathrm{Al}-\mathrm{Si}$ layer at three temperatures. The predicted redistribution of $\mathrm{Cu}$ from $\mathrm{Cu}_{3} \mathrm{Si}$ to a strong sink at each temperature is also shown (dashed lines).

FIG. 3. SIMS depth profiles of $\mathrm{Al}$ and gettered $\mathrm{Cu}$ in $\mathrm{Si}$ after annealing (a) at $600^{\circ} \mathrm{C}$ for 50 hours, and (b) at $800^{\circ} \mathrm{C}$ for 8 hours, where the $\mathrm{Cu}$ was gettered from $\mathrm{Cu}_{3} \mathrm{Si}$ located on the opposite side of a $0.25-\mathrm{mm}$ wafer.

FIG. 4. Diffusive redistribution of $\mathrm{Cu}$ from a precipitated Al-Si layer to another precipitated Al-Si layer at $700^{\circ} \mathrm{C}$. The redistribution of $\mathrm{Cu}$ from $\mathrm{Cu}_{3} \mathrm{Si}$ to an $\mathrm{Al}-\mathrm{Si}$ layer at $700^{\circ} \mathrm{C}$ (from Fig. 2) is also shown (dashed line) for comparison.

FIG. 5. SIMS depth profiles of the second precipitated $\mathrm{Al}$ layer in $\mathrm{Si}$ showing the $\mathrm{Al}$ and gettered $\mathrm{Cu}$ after annealing at $700^{\circ} \mathrm{C}$ for 2 hours, where the $\mathrm{Cu}$ was transferred from the first precipitated Al layer on the opposite side of a $0.25-\mathrm{mm}$ wafer. 


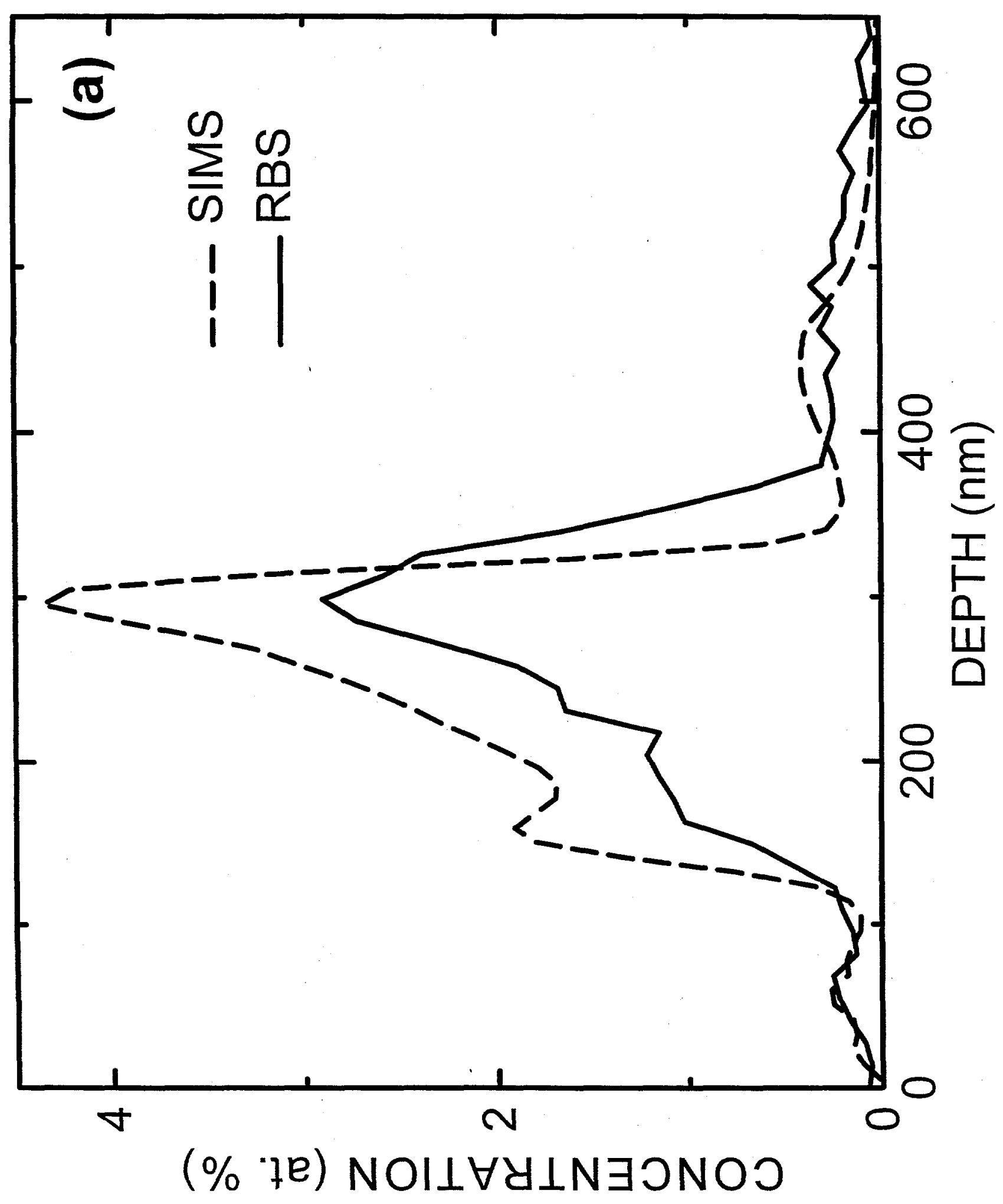




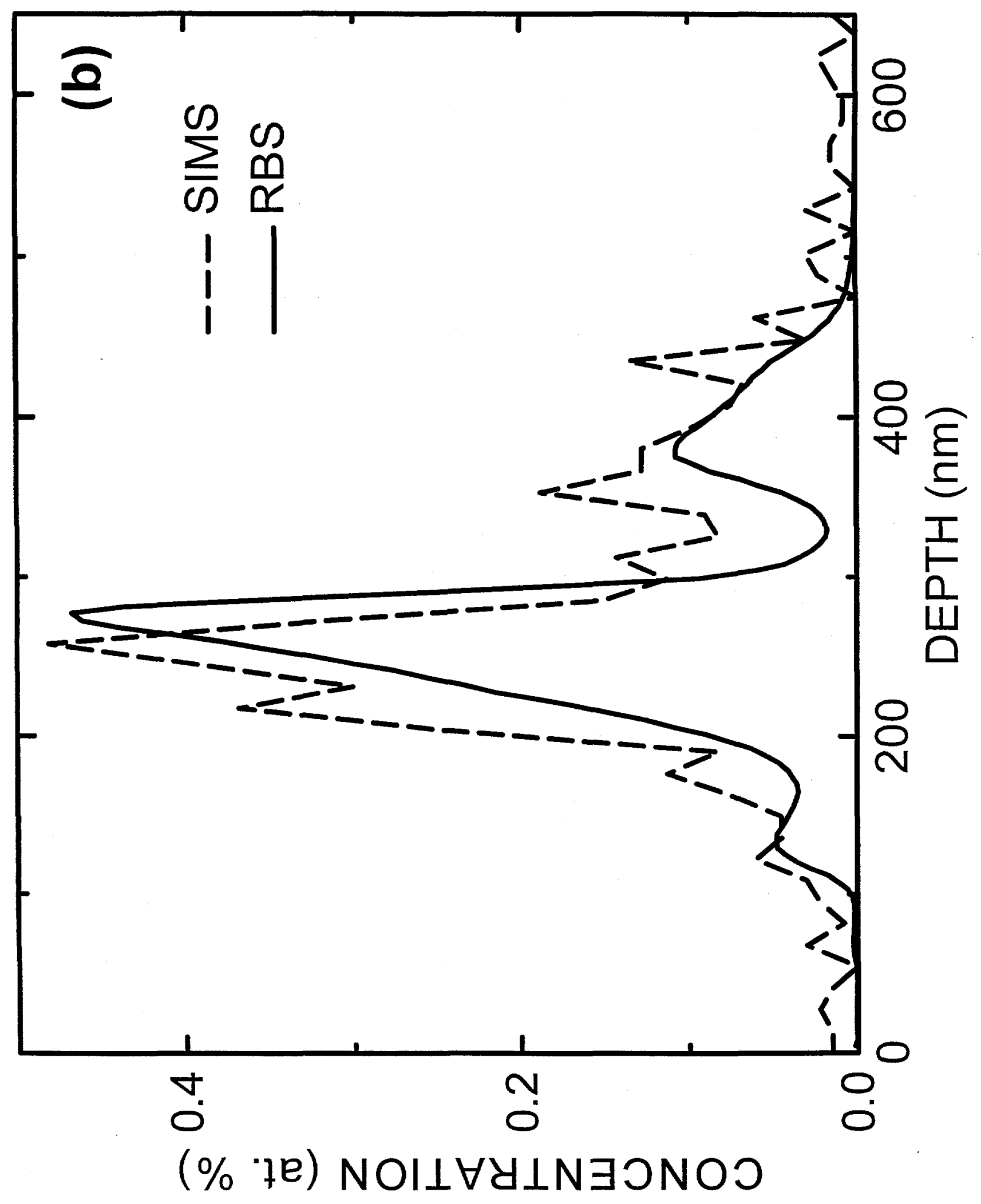


(N)

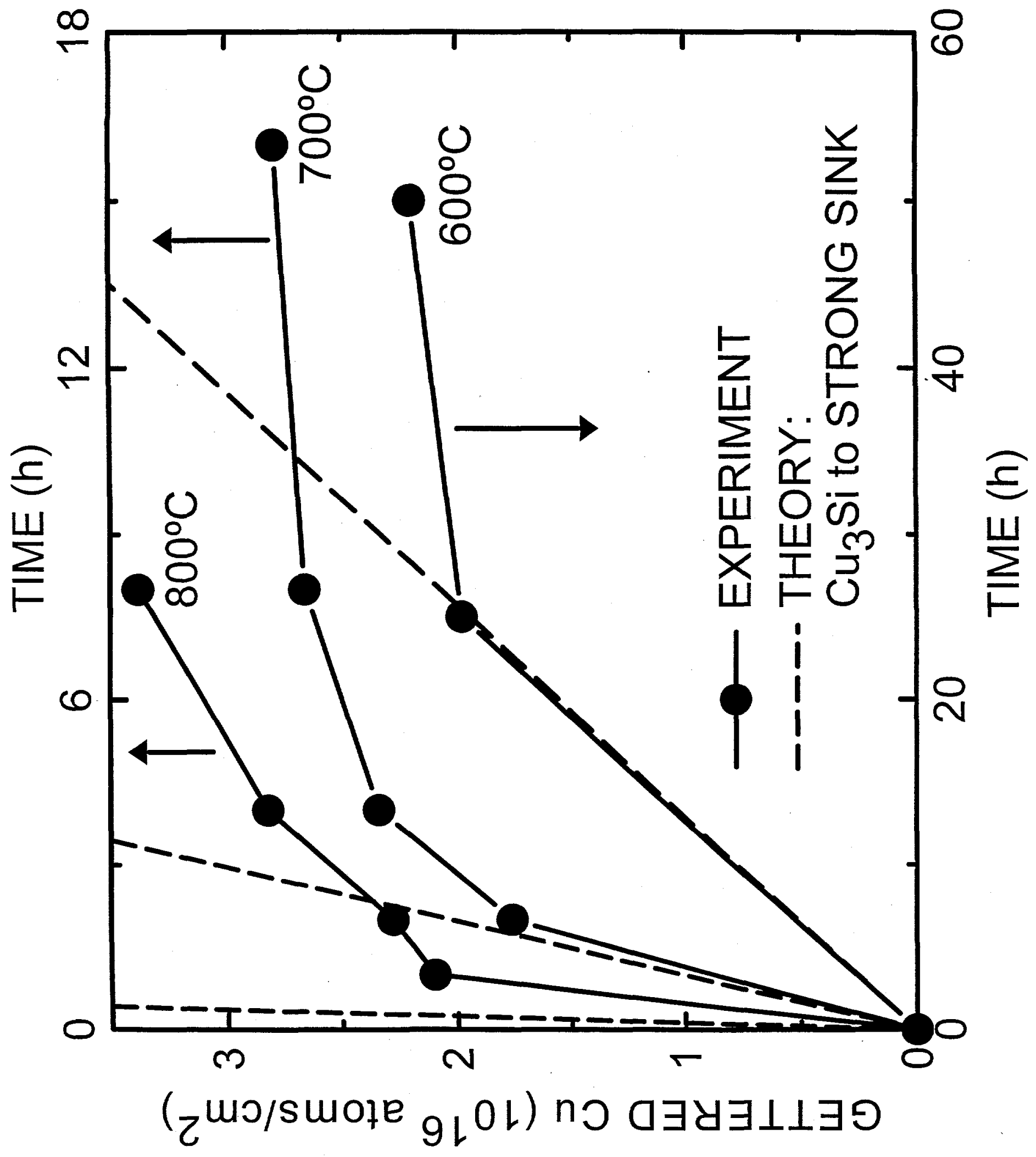





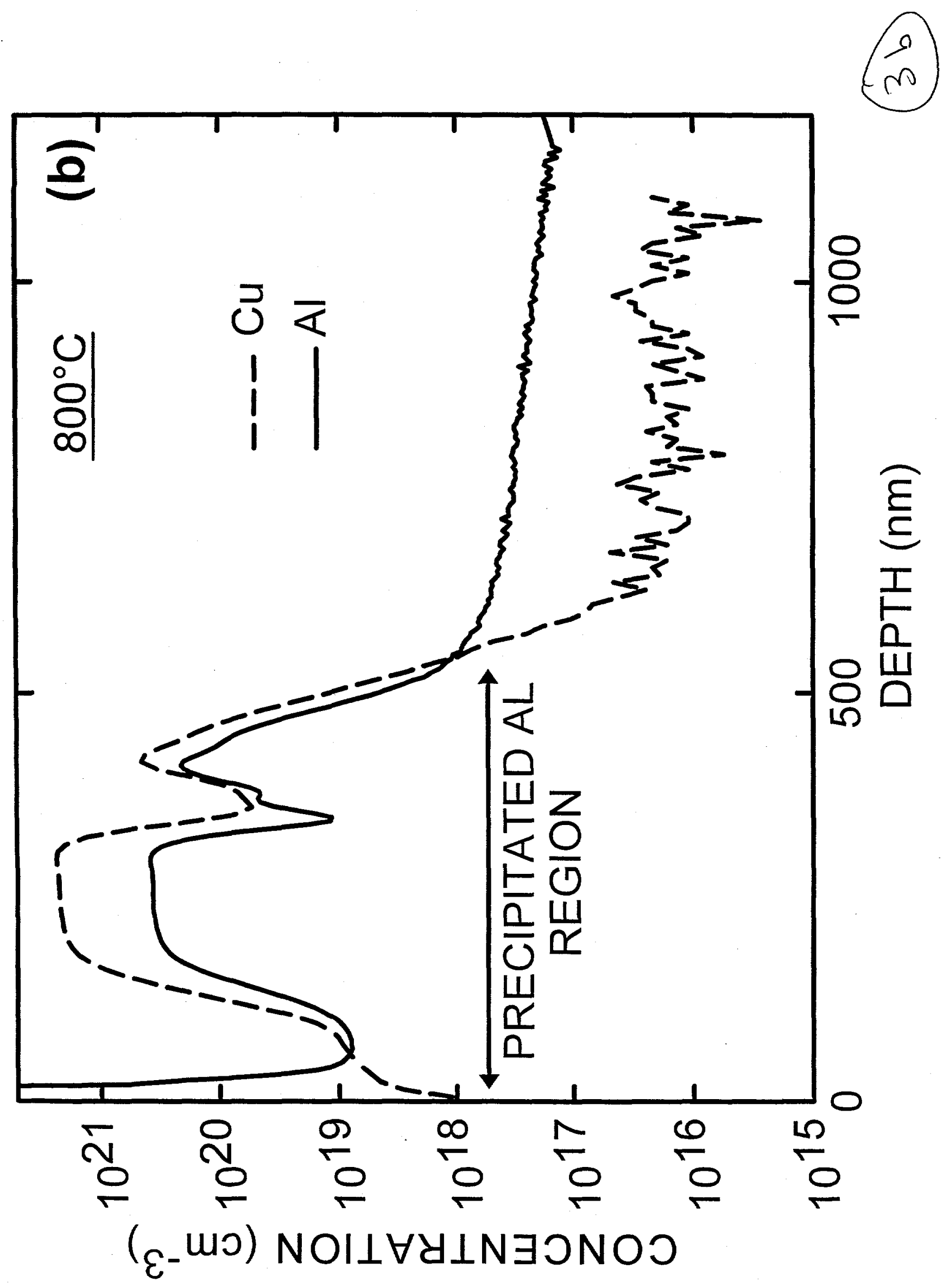




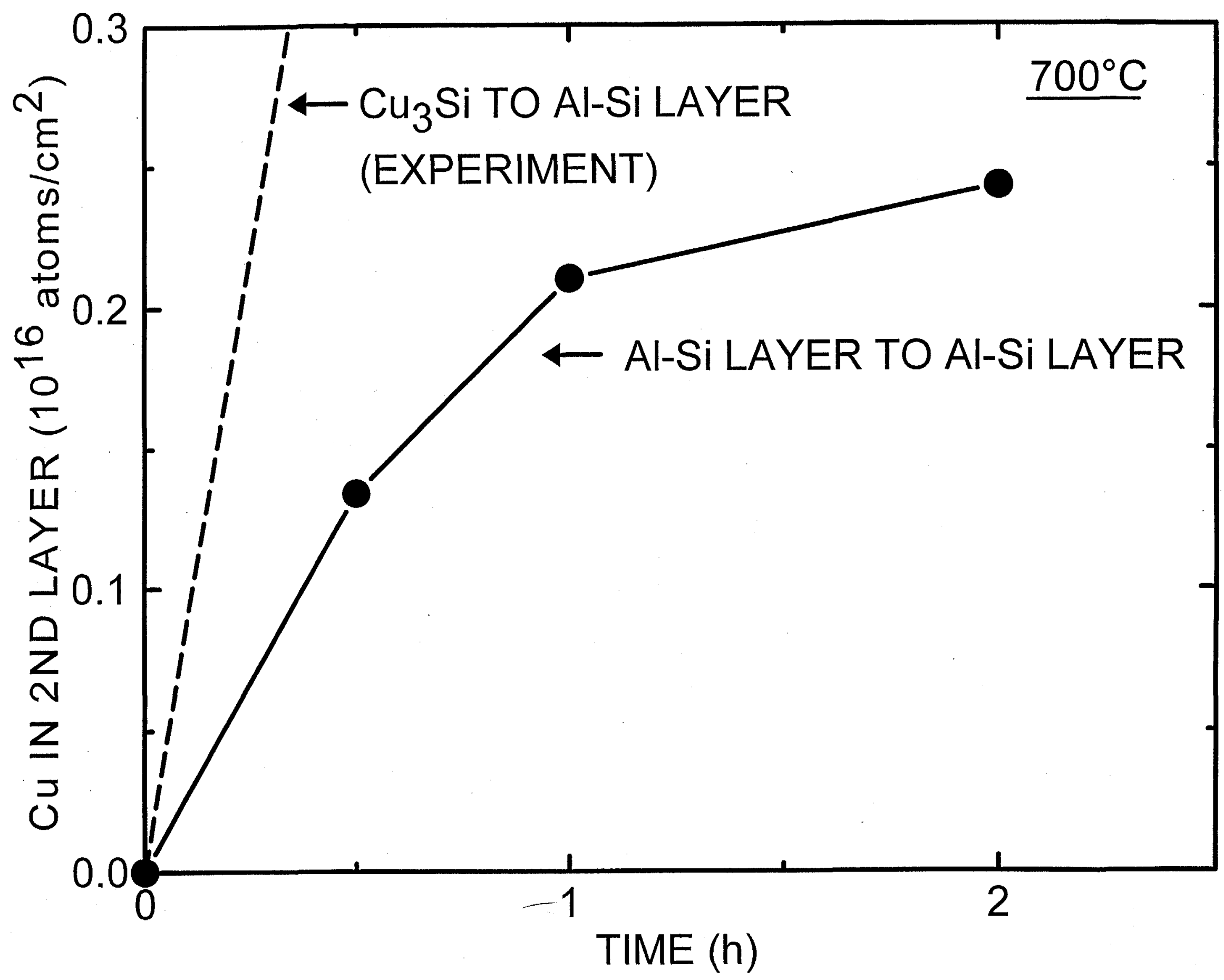




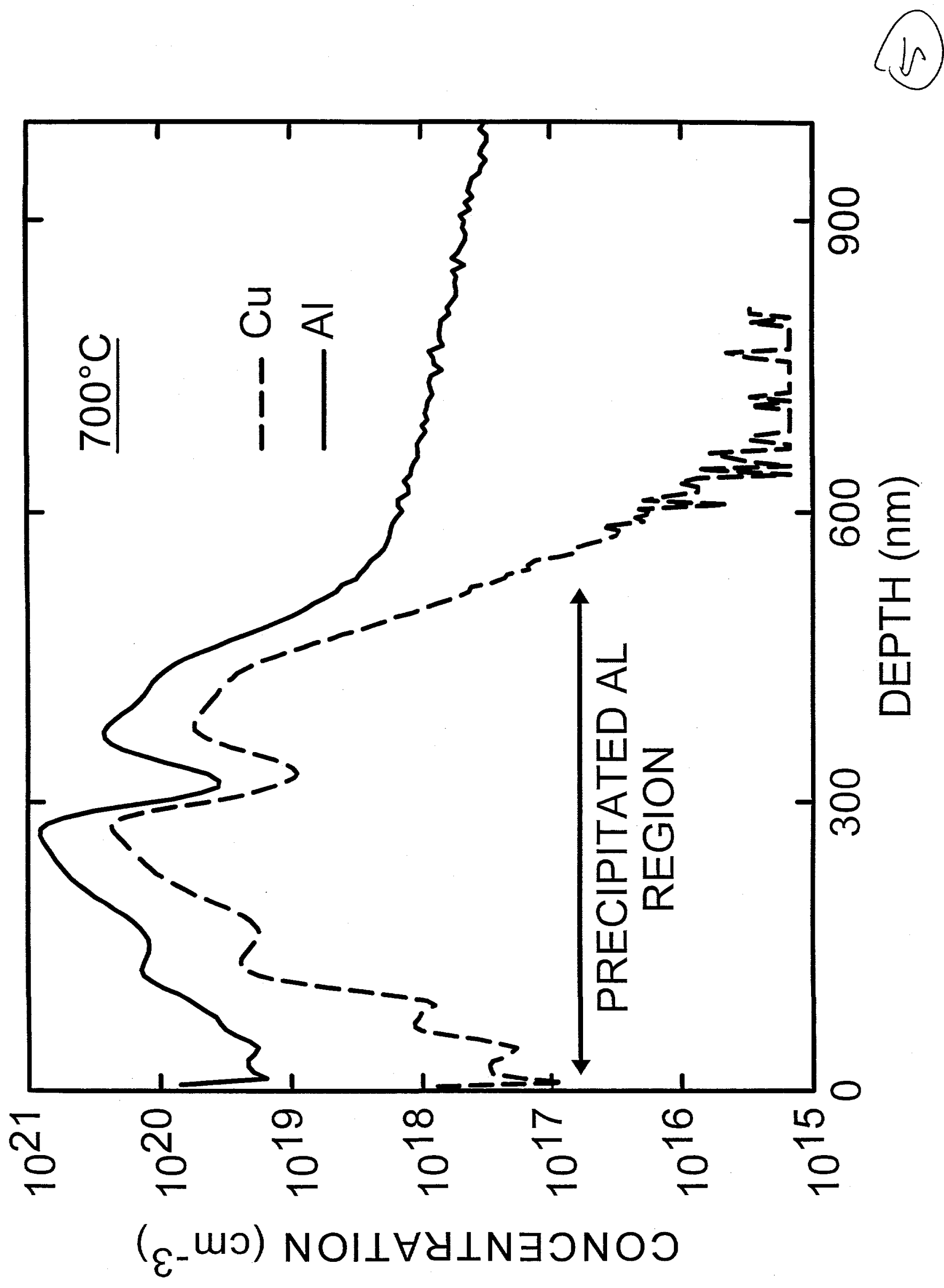

